\title{
Development of a New Colorimetric Chemosensor for Selective Determination of Urinary and Vegetable Oxalate Concentration Through an Indicator Displacement Assay (IDA) in Aqueous Media
}

\author{
Hossein Tavallali*, \\ Gohar Deilamy-Rad and \\ Narges Mosallanejad
}

Department of Chemistry, Payame Noor University, P.O. Box 19395-3697, Tehran, Iran

Received: 14 February 2018 Accepted: 8 May 2018

${ }^{*}$ Corresponding author:

Phone: +989173153520;

Fax: +987136222249 ;

E-mail:Tavallali@pnu.ac.ir

ORCID IDs: 0000-0002-9370-153X (Tavallali), 0000-0003-3022-3638

(Deilamy-Rad), 0000-0002-4009-1256 (Mosallanejad)

\section{SUMMARY}

The paper proposes a method that exhibits operational simplicity for the indirect spectrophotometric determination of oxalate ion. We developed Reactive Blue 4 (RB4) as a sensor by complexation with copper ion as a simple, inexpensive yet selective colorimetric chemosensing ensemble for the recognition of oxalate over other available competitive analytes via indicator displacement assay (IDA) in both solution (aqueous medium) and solid state (paper-based experiment). The addition of oxalate to RB4-Cu ${ }^{2+}$ complex changed the colour from sky blue to dark blue due to the regeneration of RB4 by the chelation of oxalate as the competitive analyte with $\mathrm{Cu}^{2+}$. The absorbance band increase is linear with oxalate concentration from 1.76 to $49.4 \mu \mathrm{mol} / \mathrm{L}$ with a detection limit of $0.62 \mu \mathrm{mol} / \mathrm{L}$. This measurement mode did not show any influence of interferences (available anions and ascorbic acid). This approach eliminated the need for the separation stages, enzymatic multiple-step reactions, sample preparation, organic solvent mixture, chemical modifications and equipment developed to a high degree of complexity. The oxalate determination gave results in different real samples such as urine, mushroom and spinach, which demonstrated the applicability of the existing method. Furthermore, this colorimetric system can serve as IMPLICATION molecular logic gate using $\mathrm{Cu}^{2+}$ and oxalate $\left(\mathrm{C}_{2} \mathrm{O}_{4}{ }^{2-}\right)$ as inputs and UV-Vis absorbance signal as the output with potential monitoring applications.

Key words: colorimetric chemosensor, indicator displacement assay, copper complex, oxalate, urine

\section{INTRODUCTION}

In recent years, the development of optical chemosensors for biologically important anions has been considerably attractive because they have applications in a wide range of biological and industrial processes $(1,2)$. The indicator-spacer-receptor approach (ISR) is the most widely used approach in the detection of anions with optical chemosensors in which the indicator (herein chromophore) is covalently attached to the receptor through a spacer. The limitations of ISR approach are the need to synthesize the sensor, and cost. The indicator displacement assay (IDA) largely circumvented this problem (3). Nowadays, this approach is popular in studying molecular recognition (4). In an IDA, an indicator first forms a reversible bond with a receptor. Then, a competitive analyte introduced into the system displaces the indicator from the receptor. Displacement and binding reaction are accompanied by a colorimetric signal and visible colour change by the naked eye (5). Based on this principle, the major requirement for an IDA is that the affinity between indicator and receptor is lower than that of the analyte-receptor complex. The interactions between the indicator or analyte and the host depend on the geometry of the guest, its charge, its hydrophobicity and the solvent system (6). IDAs have been used to sense both cations and anions. However, the majority of IDAs have been for anions (7). Many anions have the fundamental roles in the industrial processes and clinical analyses (8). Oxalate $\left(\mathrm{C}_{2} \mathrm{O}_{4}{ }^{2-}\right)$, as one of the most common nutrient chelates in the human diet, is of great interest due to its vital role in chemical and biochemical processes (9). The protein metabolism causes the production of oxalate in the human body (10). The high concentration of oxalate 
in urine or blood is dangerous and may cause a number of maladies including renal failure, chronic disease of the heart muscle, pancreatic insufficiency, and the development of kidney stones $(11,12)$. The insoluble complex salt with calcium $\left(\mathrm{CaC}_{2} \mathrm{O}_{4}\right)$ may be an end product of amino acid or ascorbate metabolism in the body. The normal level of urinary oxalate excretion is in the range of $110-460 \mu \mathrm{mol}$ in $24 \mathrm{~h}$ (13). Therefore, the quantification of oxalate in human urine is important. Furthermore, the determination of oxalate content in food is also important since the low oxalate diet is sometimes necessary for the treatment. Several methods developed in recent years to determine the concentration of oxalate include chromatography (14), chemiluminescence (15), amperometry $(16,17)$, flow injection analysis (18), electrochemistry (19), capillary zone electrophoresis (20), and enzyme-based methods (21). However, most of these approaches require a high cost for the operation, special equipment, and long time for tedious preparation of the sample. Therefore, the chemistry of simple and efficient receptors for the selective recognition of oxalate, particularly at physiological $\mathrm{pH}$ in different samples, is still important for researchers.

Colorimetric IDA-based sensors as user-friendly devices have many advantages including simple operation, versatility, sufficiently short response time, and relatively cheap cost as well as sensitive optical readout for the analyte $(3,22)$. Until now, some fluorometric and colorimetric displacement approaches have been developed due to the utilization of high affinity of oxalate with metal ions (2,23-26). Nevertheless, some of these time-consuming and labour-intensive approaches need complicated synthetic processing of primary material $(2,23)$.

In this study, we applied the colorimetric IDA approach for rapid, simple, selective and cost-effective detection of oxalate in biological samples by taking advantage of the $\mathrm{Cu}^{2+}$ -oxalate affinity pair. Reactive Blue 4 dye (RB4) in a complex with $\mathrm{Cu}^{2+}$, as an appropriate colorimetric indicator, and oxalate, as a competitive analyte, were employed. After treatment of $\mathrm{Cu}^{2+}$ with RB4 (the formation of the RB4-Cu${ }^{2+} \mathrm{com}-$ plex) in aqueous medium (10 mmol/L HEPES buffer solution, $\mathrm{pH}=7$ ), the colour and the colorimetric signal of RB4 exhibited changes that were observable by the naked eye. The proposed IDA system can also successfully determine oxalate concentration in urine, spinach and mushroom. Furthermore, the proposed method could be used as a paper-based analytical device and IMPLICATION molecular logic gate using $\mathrm{Cu}^{2+}$ and oxalate $\left(\mathrm{C}_{2} \mathrm{O}_{4}{ }^{2-}\right)$ as inputs and UV-Vis absorbance signal as the output with potential monitoring applications.

\section{MATERIALS AND METHODS}

\section{Materials and apparatus}

Reactive Blue 4 (RB4), an anthraquinone dye (1-amino-4-[3-(4,6-dichlorotriazin-2-ylamino)-4-sulfophenylamino]anthraquinone-2-sulfonic acid), was obtained from Merck (Darmstadt, Germany). Demineralized water was used to prepare the solutions. $\mathrm{Cu}\left(\mathrm{NO}_{3}\right)_{2}, \mathrm{KF}, \mathrm{KCl}, \mathrm{K}_{2} \mathrm{CO}_{3}, \mathrm{Na}_{2} \mathrm{HPO}_{4}$ $\mathrm{K}_{3} \mathrm{PO}_{4}, \mathrm{Na}_{2} \mathrm{SO}_{4}, \mathrm{KNO}_{3}, \mathrm{NaC}_{2} \mathrm{H}_{3} \mathrm{O}_{2}, \mathrm{KClO}_{4}, \mathrm{~K}_{2} \mathrm{C}_{2} \mathrm{O}_{4}$ and ascorbic acid $\left(\mathrm{C}_{6} \mathrm{H}_{8} \mathrm{O}_{6}\right)$ were purchased from Merck. Stock solution (10-2 $\mathrm{mol} / \mathrm{L}$ ) of analytes was prepared by direct dissolution of their proper amount in deionized water. All other chemicals were of analytical grade and used as received. The buffer solution was prepared using 4-(2-hydroxyethyl)-1-piperazine ethane sulfonic acid (HEPES).

A Shimadzu 1601 PC UV-Vis double beam spectrometer (Kyoto, Japan) was used to record all UV-Vis spectra in quartz cuvettes $10.0 \mathrm{~mm}$ in diameter. A Bruker Vector 22 Fourier transform infrared spectrometer (Billerica, MA, USA) recorded the FTIR spectra using $\mathrm{KBr}$ pellet method. A digital Jenway 3510 digital $\mathrm{pH}$ meter (London, UK) calibrated with two standard buffer solutions was used to measure various $\mathrm{pH}$ values. A Hamilton syringe of $50 \mu \mathrm{L}$ was used to deliver desired amounts of analyte solution into the cuvette.

\section{General procedure}

The adjusted temperature in all titration experiments was $298.2 \mathrm{~K}$. The $5 \cdot 10^{-5} \mathrm{~mol} / \mathrm{L}$ solution of RB4 was prepared by the dilution of its $10^{-2} \mathrm{~mol} / \mathrm{L}$ stock solution in aqueous medium (10 $\mathrm{mmol} / \mathrm{L}$ HEPES buffer solution, $\mathrm{pH}=7$ ). Then the UV-Vis absorption spectra of RB4 were recorded by transferring $2.5 \mathrm{~mL}$ of this diluted solution to the quartz cuvette. For complexation study, a $10^{-2} \mathrm{~mol} / \mathrm{L}$ aqueous solution of the nitrate salt of $\mathrm{Cu}^{2+}$ was prepared. The detection of oxalate and its effect on the colour and absorption spectra of the RB4-Cu${ }^{2+}$ solution were studied by preparing the oxalate solution and gradually adding it (1.76-96.0 $\mu \mathrm{mol} / \mathrm{L})$ with microlitre syringe to the solution containing RB4 complex with $\mathrm{Cu}^{2+}$. Then, the UV-Vis spectra were recorded. Subsequently, the interactions and the stoichiometry ratios (Yoe and Jones method (27) or the mole ratio method $(28,29))$ were studied.

\section{Preparation of test paper for onsite visual determination of oxalate}

Test papers were fabricated by immersing ordinary filter papers into the aqueous solution of RB4 $(0.1 \mathrm{~mol} / \mathrm{L})$ and $\mathrm{Cu}^{2+}$ $(0.1 \mathrm{~mol} / \mathrm{L})$, respectively, dried at room temperature and then used for the determination of oxalate in aqueous solutions. The corresponding colour change was observed by the naked eye.

\section{Real sample preparation}

\section{Preparation of urine sample}

An aliquot of $5 \mathrm{~mL}$ of urine sample collected in sterilized polyethylene tube was transferred to a $50-\mathrm{mL}$ volumetric flask, made up to the mark $(\mathrm{pH}=7)$, and shaken for $5 \mathrm{~min}$. Then, $20 \mathrm{~mL}$ of this solution were taken and transferred to a $50-\mathrm{mL}$ beaker. Then, the oxalate content was determined by the colorimetric method mentioned above. 
Preparation of mushroom and spinach samples

A mass of $3 \mathrm{~g}$ fresh spinach or $15 \mathrm{~g}$ fresh mushroom was cut into small pieces with a razor blade, and then homogenized with a mortar and pestle. Subsequently, the obtained paste was mixed with water, diluted to $100 \mathrm{~mL}$ in a calibrated flask, boiled for $45 \mathrm{~min}$ and then cooled. The filtration of the suspension was done through Whatman no. 1 filter paper. The filtrate was diluted to $250 \mathrm{~mL}$. Then, the $\mathrm{pH}$ of the obtained solution was adjusted to about 10 by dropwise addition of $0.1 \mathrm{~mol} / \mathrm{L} \mathrm{NaOH}$ solution to remove the interference effect of iron cations. The solution was centrifuged (MS-3400 centrifuge; Cole-Parmer ${ }^{\circledR}$, St. Neots, UK) at $1492 \times g$ for $5 \mathrm{~min}$. After the neutralization of the solution with $0.1 \mathrm{~mol} / \mathrm{L} \mathrm{HCl}$ solution, it was diluted in a $100-\mathrm{mL}$ volumetric flask. A suitable aliquot of the obtained solution was used for the determination of oxalate content with the proposed method.

\section{Reference method}

After preparation of the test sample solution, it was transferred to a $250-\mathrm{mL}$ Erlenmeyer flask. A volume of $50 \mathrm{~mL}$ distilled water and $20 \mathrm{~mL}$ of $3 \mathrm{M} \mathrm{H}_{2} \mathrm{SO}_{4}$ were added and stirred to dissolve the solid. The acidified solution was heated to about $85^{\circ} \mathrm{C}$. A mass of $1 \mathrm{~g} \mathrm{KMnO}_{4}$ was transferred to a $500-\mathrm{mL}$ volumetric flask, $350 \mathrm{~mL}$ distilled water were added, and the solution was heated for $30 \mathrm{~min}$. The hot sample solution was titrated with the cool $\mathrm{KMnO}_{4}$ solution to determine the endpoint (30).

\section{RESULTS AND DISCUSSION}

\section{Design of the colorimetric sensor for determination of oxalate based on IDA principle}

A simple oxalate colorimetric chemosensor was designed based on indicator displacement assay. For IDA, the indicator must bind to host reversibly and cause the change in spectroscopic signal. In this experiment, RB4 is a colorimetric indicator to form the RB4-Cu${ }^{2+}$ complex. The interaction between RB4 and $\mathrm{Cu}^{2+}$ was investigated by UV-Vis spectroscopy. Fig. 1a shows that RB4 (50 $\mu \mathrm{mol} / \mathrm{L})$ in aqueous solution ( $10 \mathrm{mmol} / \mathrm{L}$ HEPES buffer solution, $\mathrm{pH}=7$ ) exhibits a maximum absorption peak at approx. $607 \mathrm{~nm}$ as well as an obvious dark blue colour. Upon gradual addition of $\mathrm{Cu}^{2+}(1.97-122 \mu \mathrm{mol} / \mathrm{L})$, the absorption intensity at 607 $\mathrm{nm}$ decreased and shifted to around $619 \mathrm{~nm}$ accompanied with a colour change from dark blue to deep sky blue (right inset, Fig. 1a). The absorbance changes versus the $\mathrm{Cu}^{2+}$ concentration increase is plotted in the left inset of Fig. 1a. A 1:1 binding of the formed complex between RB4 and $\mathrm{Cu}^{2+}$ was confirmed by Yoe and Jones method (Fig. S1; supplementary material available at: www.ftb.com.hr) (27-29). The binding constant $\left(K_{\mathrm{s}}\right)$ of the [RB4$\left.-\mathrm{Cu}^{2+}\right]$ complex was also estimated to be $(4.46 \pm 0.12) \cdot 10^{5} \mathrm{~L} / \mathrm{mol}$ by nonlinear curve fitting (31).

The colorimetric response of $\left[\mathrm{RB} 4-\mathrm{Cu}^{2+}\right]$ complex towards oxalate was studied by the UV-Vis spectrometric titration experiment. When oxalate ion was added gradually (1.76-96.0 $\mu \mathrm{mol} / \mathrm{L}$ ) to the complex solution, the absorption band intensity increased at $607 \mathrm{~nm}$ (Fig.1b). The colour of the solution also gradually changed from deep sky blue to dark blue (right inset, Fig. 1b). Left inset in Fig. 1b is also the graph of the UV-Vis absorption changes of the RB4-Cu ${ }^{2+}$ complex as a function of the concentration of oxalate ( $\mathrm{mol} / \mathrm{L}$ ). The absorption spectra and the obtained colour were identical with that of RB4. This colorimetric change indicates that $\left[\mathrm{RB} 4-\mathrm{Cu}^{2+}\right.$ complex can be used for the determination of oxalate by the naked eye.

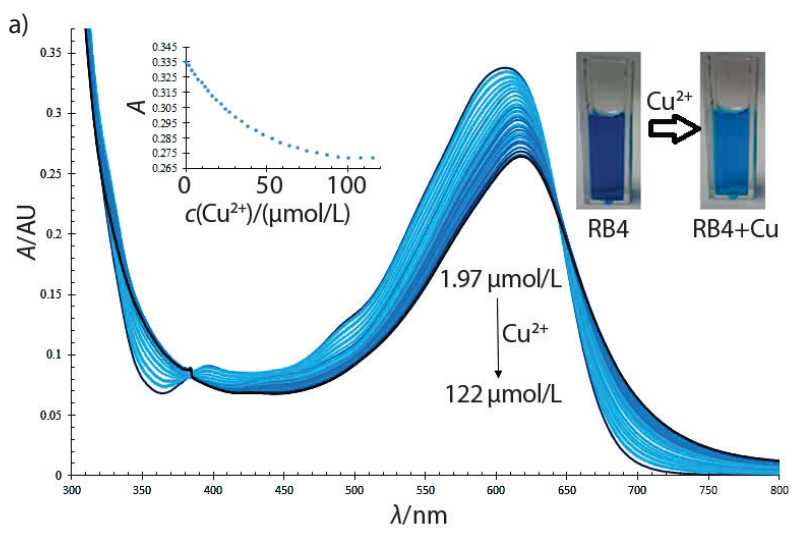

b)

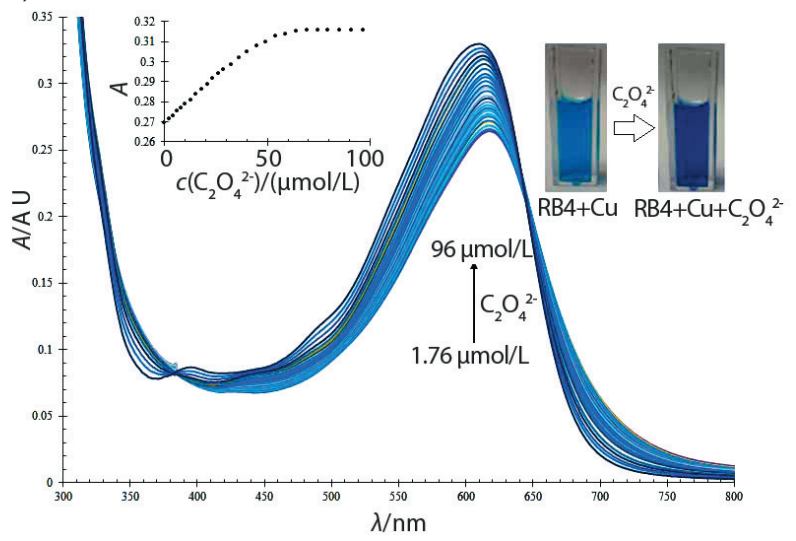

Fig. 1. The UV-Vis spectrum of: a) Reactive Blue 4 dye $\left(\mathrm{RB}_{4} ; 50 \mu \mathrm{mol} / \mathrm{L}\right)$ with different concentrations of copper ions. Left inset is the graph of the UV-Vis absorption changes of RB4 at $607 \mathrm{~nm}$ as a function of the concentration of $\mathrm{Cu}^{2+}(\mu \mathrm{mol} / \mathrm{L})$. Right inset is the photograph of the corresponding solution (the colour change from dark blue to deep sky blue); b) RB4-Cu' ${ }^{2+}$ complex (equimolar concentration of 50 $\mu \mathrm{mol} / \mathrm{L} \mathrm{RB} 4$ with $50 \mu \mathrm{mol} / \mathrm{L} \mathrm{Cu}^{2+}$ ) after the addition of different oxalate concentrations. Left inset is the graph of the UV-Vis absorption changes of the RB4-Cu ${ }^{2+}$ complex as a function of the concentration of oxalate. Right inset is the photograph of the solution colour change from deep sky blue to dark blue

The application of the Yoe and Jones method (27-29) by plotting the absorbance at $607 \mathrm{~nm}$ versus the molar ratio of $\mathrm{C}_{2} \mathrm{O}_{4}{ }^{2-}$ to $\mathrm{Cu}^{2+}$ confirmed a stoichiometry of $1: 1$ for the interaction of $\mathrm{Cu}^{2+}$ and $\mathrm{C}_{2} \mathrm{O}_{4}{ }^{2-}$ (Fig. 2) with the association constant $K_{\mathrm{s}}=(2.3 \pm 0.1) \cdot 10^{7} \mathrm{~L} / \mathrm{mol}$ obtained by nonlinear curve fitting (Fig. S2) $(31,32)$. Two oxygen atoms from oxalate act as a bidentate ligand. Thus, the displacement process can be as follows:

$$
\mathrm{RB} 4-\mathrm{Cu}^{2+}+\mathrm{C}_{2} \mathrm{O}_{4}{ }^{2-} \rightarrow \mathrm{CuC}_{2} \mathrm{O}_{4}+\mathrm{RB} 4
$$

As mentioned above, the binding constant of $\mathrm{Cu}^{2+}$ with oxalate is larger than that of $\mathrm{Cu}^{2+}$ with RB4. Therefore, the indicator displacement by oxalate is highly favourable due to higher affinity of oxalate towards $\mathrm{Cu}^{2+}$. 
a)
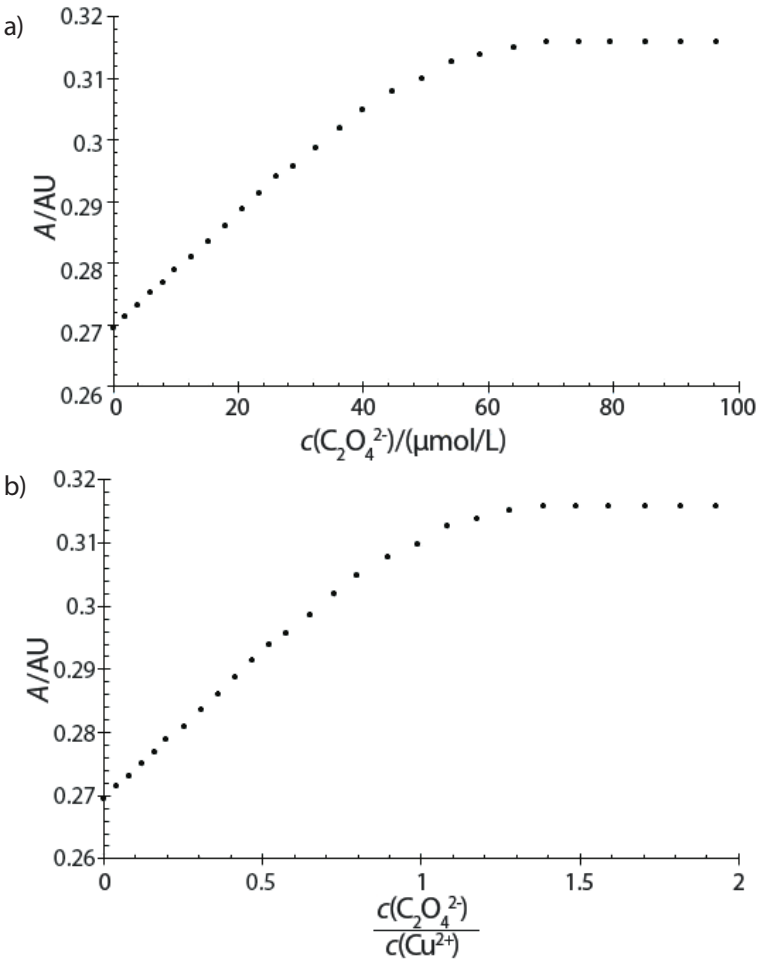

Fig. 2. The graphs show: a) the increased absorbance at $607 \mathrm{~nm}$ as a function of the concentration of oxalate $(1.76-96.0 \mu \mathrm{mol} / \mathrm{L})$ added to Reactive Blue 4-Cu ${ }^{2+}$ complex $\left(50 \mu \mathrm{mol} / \mathrm{L} \mathrm{RB} 4\right.$ with $\left.50 \mu \mathrm{mol} / \mathrm{L} \mathrm{Cu}^{2+}\right)$ in $10 \mathrm{mmol} / \mathrm{L}$ HEPES buffer solution, $\mathrm{pH}=7$, and $\mathrm{b}$ ) the absorbance at 607 $\mathrm{nm}$ as a function of the molar ratio of oxalate to $50 \mu \mathrm{mol} / \mathrm{L} \mathrm{Cu}^{2+}$ in 10 $\mathrm{mmol} / \mathrm{L}$ HEPES buffer solution, $\mathrm{pH}=7$

\section{Study of selectivity towards oxalate}

The selectivity of the proposed chemosensor towards oxalate ion in the presence of ascorbic acid and other anions was investigated. The solution system was selective towards oxalate anion over ascorbic acid $\left(\mathrm{C}_{6} \mathrm{H}_{8} \mathrm{O}_{6}\right), \mathrm{SO}_{4}{ }^{2-}, \mathrm{NO}_{3}{ }^{-}, \mathrm{CO}_{3}{ }^{2-}$, $\mathrm{HPO}_{4}{ }^{2-}, \mathrm{PO}_{4}{ }^{3-}, \mathrm{AcO}^{-}, \mathrm{ClO}_{4}{ }^{-}, \mathrm{F}^{-}, \mathrm{Cl}^{-}$and $\mathrm{Br}^{-}$(Fig. 3). Only the oxalate anion is able to generate colour and spectral changes. When ascorbic acid and other anions $(500 \mu \mathrm{mol} / \mathrm{L})$ were added into the $\left[\mathrm{RB} 4-\mathrm{Cu}^{2+}\right.$ complex solution, negligible changes in colour and UV-Vis spectrum were observed, showing that they do not interfere with the detection of the presence or amount of oxalate anion. Therefore, it was proven that this chemosensor has selectivity towards oxalate in water solution without the need for sophisticated instruments.

\section{Possible mechanism study}

Scheme 1 shows the proposed IDA strategy for the determination of oxalate $\left(\mathrm{C}_{2} \mathrm{O}_{4}{ }^{2-}\right)$. This strategy is based on the competition of the analyte and the chromogenic indicator (RB4) for the interaction with $\mathrm{Cu}^{2+}$. As already mentioned, a 1:1 complex with the stability constant of $(4.46 \pm 0.12) \cdot 10^{5} \mathrm{~L} / \mathrm{mol}$ formed after the addition of $\mathrm{Cu}^{2+}$ to the RB4 solution. There are some changes in the FTIR spectrum of the RB4-Cu${ }^{2+} \mathrm{Com}-$ plex from 1570 to $1616 \mathrm{~cm}^{-1}$ (B in Fig. 4). Obviously, the frequency of the $\mathrm{N}-\mathrm{H}$ (primary amine) bending vibration weakened at $1570 \mathrm{~cm}^{-1}$. At the same time, the frequency of the

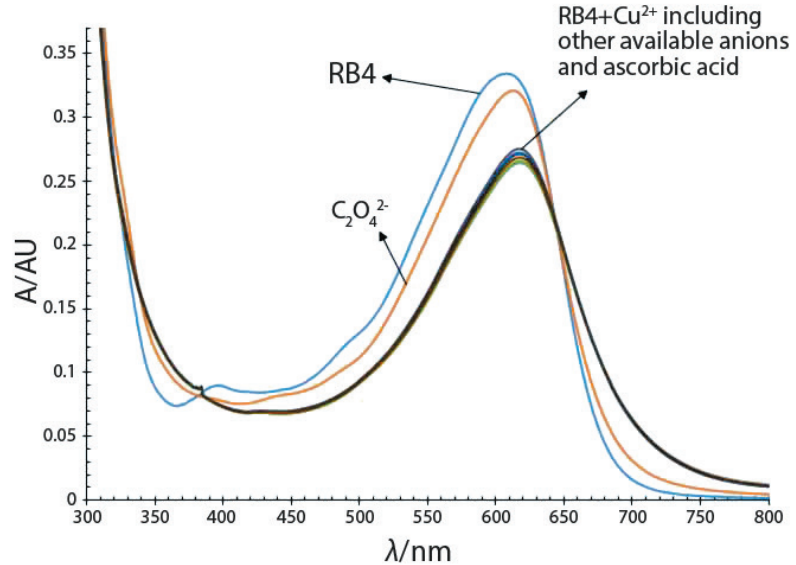

Fig. 3. UV-Vis spectra of Reactive Blue 4 (RB4; $50 \mu \mathrm{mol} / \mathrm{L})$, [RB4-Cu$\left.{ }^{2+}\right]$ complex in the presence of $(c=500 \mu \mathrm{mol} / \mathrm{L})$ : ascorbic acid, $\mathrm{F}^{-}, \mathrm{Cl}^{-}, \mathrm{Br}$, $\mathrm{CO}_{3}{ }^{2-}, \mathrm{HPO}_{4}{ }^{2-}, \mathrm{PO}_{4}{ }^{3-}, \mathrm{SO}_{4}{ }^{2-}, \mathrm{NO}_{3}{ }^{-}, \mathrm{AcO}^{-}, \mathrm{ClO}_{4}{ }^{-}$, and $\left[\mathrm{RB} 4-\mathrm{Cu}^{2+}\right]$ complex with $c\left(\mathrm{C}_{2} \mathrm{O}_{4}^{2-}\right)=50 \mu \mathrm{mol} / \mathrm{L}$ in the presence of $(c=500 \mu \mathrm{mol} / \mathrm{L})$ : ascorbic acid, $\mathrm{F}^{-}, \mathrm{Cl}^{-}, \mathrm{Br}^{-}, \mathrm{CO}_{3}{ }^{2-}, \mathrm{HPO}_{4}{ }^{2-}, \mathrm{PO}_{4}{ }^{3-}, \mathrm{SO}_{4}{ }^{2-}, \mathrm{NO}_{3}{ }^{-}, \mathrm{AcO}^{-}$and $\mathrm{ClO}_{4}{ }^{-}$
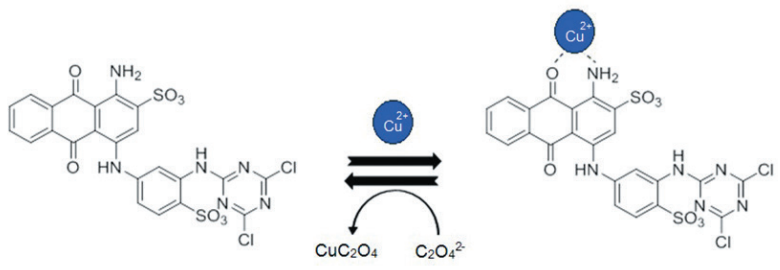

Scheme 1. Illustration of the proposed reaction mechanism of Reactive Blue 4 (RB4) with $\mathrm{Cu}^{2+}$ and oxalate $\left(\mathrm{C}_{2} \mathrm{O}_{4}{ }^{2-}\right)$ ions

$\mathrm{C}=\mathrm{O}$ stretching vibration also shifted from 1616 to $1603 \mathrm{~cm}^{-1}$. Furthermore, one band was observed at $692 \mathrm{~cm}^{-1}$, which is attributed to $\mathrm{Cu}-\mathrm{O}$ stretching. The existence of these changes suggests that $-\mathrm{NH}_{2}$ and $\mathrm{C}=\mathrm{O}$ groups can participate in the coordination (Scheme 1).

In FTIR spectrum of RB4- $\mathrm{Cu}^{2+}+\mathrm{C}_{2} \mathrm{O}_{4}{ }^{2-}$ ( $\mathrm{C}$ in Fig. 4), the existence of the frequencies of $\mathrm{C}=\mathrm{O},-\mathrm{NH}_{2}, \mathrm{~S}=\mathrm{O}, \mathrm{C}-\mathrm{Cl}$ stretching vibrations, $\mathrm{C}-\mathrm{N}-\mathrm{C}$ triazine bending vibration and $\mathrm{N}-\mathrm{H}$ wag

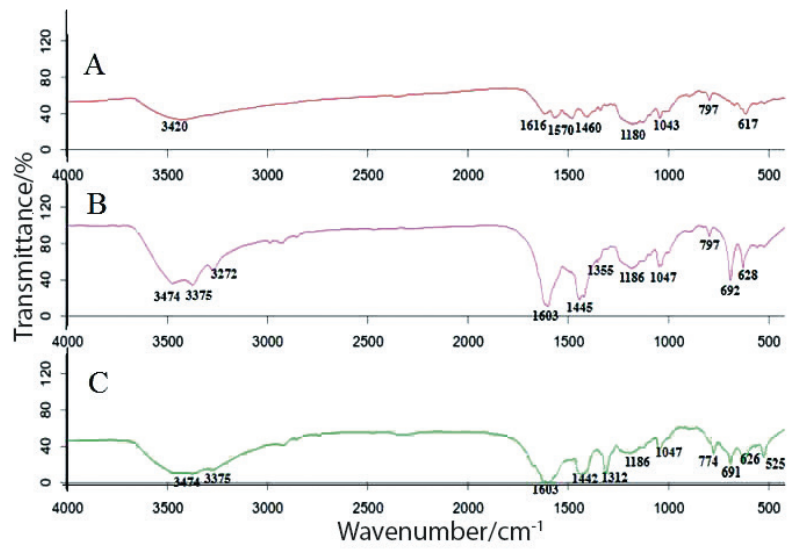

Fig. 4. Comparison of the IR spectra of the proposed colorimetric sensor based on indicator displacement assay (IDA) strategy after adding $\mathrm{Cu}^{2+}$ and $\mathrm{C}_{2} \mathrm{O}_{4}{ }^{2-}$ utilizing $\mathrm{KBr}$ pellet method 
shows that these groups are free and do not participate in coordination. Furthermore, the bands observed at 1312 and 525 $\mathrm{cm}^{-1}$ correspond to the stretching vibrations of $\mathrm{C}-\mathrm{O}$ of oxalate and $\mathrm{Cu}-\mathrm{OCCO}$, respectively. The presence of these bands indicates the $\mathrm{Cu}-\mathrm{C}_{2} \mathrm{O}_{4}{ }^{2-}$ association, which can imply better affinity of oxalate towards $\mathrm{Cu}^{2+}$ than that of RB4 (Scheme 1). The addition of $\mathrm{C}_{2} \mathrm{O}_{4}{ }^{2-}$ to the $\mathrm{RB} 4-\mathrm{Cu}^{2+}$ complex solution restored the colour and spectrum of RB4 (Fig. 5). $\mathrm{C}_{2} \mathrm{O}_{4}{ }^{2-}$ has a stronger binding capability with $\mathrm{Cu}^{2+}$ ion than with $\mathrm{RB} 4$ and can form a more stable $\mathrm{CuC}_{2} \mathrm{O}_{4}$, so after the addition of $\mathrm{C}_{2} \mathrm{O}_{4}$, the UV-Vis absorption spectrum and colour of RB4 were recovered and the colour and absorbance changes were reversible with the addition of $\mathrm{Cu}^{2+}$ and $\mathrm{C}_{2} \mathrm{O}_{4}{ }^{2-}$.

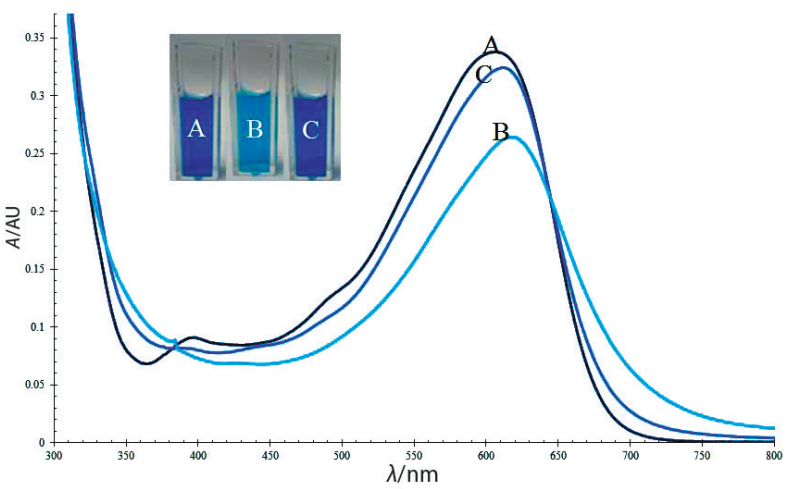

Fig. 5. The absorption curves of $50 \mu \mathrm{mol} / \mathrm{L}$ Reactive Blue 4 (RB4) dye (A), $50 \mu \mathrm{mol} / \mathrm{L}$ RB4 and $50 \mu \mathrm{mol} / \mathrm{L} \mathrm{Cu}^{2+}$ (B), A+B+50 $\mu \mathrm{mol} / \mathrm{L}$ oxalate ion $(C)$. Insert is the photograph of the corresponding solution ( $A$ : $50 \mu \mathrm{mol} / \mathrm{L}$ RB4 with dark blue, B: $\mathrm{A}+50 \mu \mathrm{mol} / \mathrm{L} \mathrm{Cu}^{2+}$ and the colour change to deep sky blue, $\mathrm{C}: \mathrm{A}+\mathrm{B}+50 \mu \mathrm{mol} / \mathrm{L} \mathrm{C}_{2} \mathrm{O}_{4}{ }^{2-}$ and the colour change to dark blue

\section{pH effect and response time}

The effective and suitable $\mathrm{pH}$ range (values between 3 and 10) for the selective determination of $\mathrm{C}_{2} \mathrm{O} 4^{2-}$ was studied. At lower $\mathrm{pH}$ values $(<5)$ and acidic conditions, the colorimetric response decreased (Fig. S3), which may be due to protonation of the heteroatoms of RB4 and the prevention of the complex formation with $\mathrm{Cu}^{2+}$. The concentration of free oxalate is also low because all oxalate ions are protonated. Oxalate is the deprotonated form of oxalic acid ( $\mathrm{p} K_{\mathrm{a} 1}=1.23$ and $\mathrm{p} K_{\mathrm{a} 2}=4.19$ ). In the acidic environment, the interaction of $\mathrm{C}_{2} \mathrm{O}_{4}{ }^{2-}$ with $\mathrm{H}^{+}$causes a decrease in $\mathrm{C}_{2} \mathrm{O}_{4}{ }^{2-}$ and $\mathrm{HC}_{2} \mathrm{O}_{4}{ }^{-}$and the production of $\mathrm{H}_{2} \mathrm{C}_{2} \mathrm{O}_{4}$.

Under alkaline conditions $(\mathrm{pH}>8)$, the colorimetric response was also weak due to the interaction of $\mathrm{Cu}^{2+}$ with hydroxide ion and the lack of the $\mathrm{RB} 4-\mathrm{Cu}^{2+}$ complex formation. However, the absorption intensity of $\left[\mathrm{RB} 4-\mathrm{Cu}^{2+}\right]$ complex solution showed significant changes only in the $\mathrm{pH}$ range of 5-7 upon the addition of oxalate (Fig. S3). Furthermore, the best colorimetric response of RB4-Cu ${ }^{2+}$ to oxalate was obtained at $\mathrm{pH}=7$. The results show that under approximately physiological conditions, the proposed chemosensor can be employed to detect oxalate.
Short response time is also another important characteristic of chemosensors in practical applications. We tested the response of the proposed chemosensor within $60 \mathrm{~min}$. The maximum response for the determination of oxalate was obtained in a satisfactorily short time (less than $1 \mathrm{~min}$ ) (Fig. S4). This fast response can provide a new real-time method for oxalate determination.

\section{Logic gate construction of the proposed colorimetric sensor}

Molecular chemosensors represent an advancement of the molecular logic gate in sensing chemistry. Here, we constructed an IMPLICATION molecular logic gate based on the proposed colorimetric indicator displacement assay (Fig. S5). Since the significant characteristic of the proposed chemosensor was its optical signal response, $\mathrm{Cu}^{2+}$ and $\mathrm{C}_{2} \mathrm{O}_{4}{ }^{2-}$ as two inputs, and the colour and the UV-Vis absorbance at 607 $\mathrm{nm}$ as outputs were defined. Numbers 0 and 1 indicate the absence and presence of the inputs, respectively. In the output, 1 and 0 define the dark blue and deep sky blue colours, respectively. The presence and/or absence of $\mathrm{C}_{2} \mathrm{O}_{4}{ }^{2-}$ and $\mathrm{Cu}^{2+}$ inputs were defined by four pairs (0/0,1/0, 0/1 and 1/1). Only one pair gives the output of 0 with an obvious deep sky blue colour and the spectral decrease due to $\left[\mathrm{RB} 4-\mathrm{Cu}^{2+}\right]$ complex formation if the $\mathrm{Cu}^{2+}$ input is 1 and $\mathrm{C}_{2} \mathrm{O}_{4}{ }^{2-} 0$ (Fig. S5a-5c). Thus, only with $\mathrm{Cu}^{2+}$ and without $\mathrm{C}_{2} \mathrm{O}_{4}{ }^{2-}$ input, the output of IMPLICATION is a deep sky blue (Fig. S5d). This logic function (Fig. S5) can be potential for oxalate determination.

\section{Colorimetric IDA-based test paper for the visual detection of oxalate}

Recently, the development of colorimetric methods along with the detection by the naked eye has been one of the subjects of interest in the analytical applications. There is an enormous interest in the colorimetric assay based on test paper as a simple, effective, fast, and low-cost sensing technology $(5,33)$. The paper-based test strips fabricated according to the instruction given in Materials and Methods section were used for colorimetric experiments. The evaluation of the practicability of the proposed colorimetric strategy is possible with these experiments. The proposed colorimetric IDA assay was repeated with the paper-based test strips and the primary colour recovery after the addition of oxalate to $\left[\mathrm{RB} 4-\mathrm{Cu}^{2+}\right]$ was observed (A in Fig. S6). Test papers immersed in different concentrations of oxalate from 0.005 to $0.1 \mathrm{~mol} / \mathrm{L}$ demonstrated different colours. This experiment can indicate the applicability of fast, simple and effective paper-based analytical strategy for oxalate determination (B in Fig. S6). A selectivity experiment was also performed using paper-based test strips. Upon the addition of anions to the $\left[\mathrm{RB} 4-\mathrm{Cu}^{2+}\right]$ complex, only oxalate showed an obvious colour change compared with other available anions (C in Fig. S6c). The obtained results can verify the applicability of the proposed colorimetric strategy for 'in-thefield' oxalate measurement. 
Table 1. Results of the determination of oxalate ion in real samples of mushroom, spinach and urine

\begin{tabular}{lcccccc}
\multicolumn{1}{c}{ Sample } & $w_{\text {experimental }}{ }^{*} /(\mathrm{mg} / \mathrm{g})$ & $w_{\text {referent }} /(\mathrm{mg} / \mathrm{g})$ & $m_{\text {added }} / \mu \mathrm{g}$ & $m_{\text {recovered }} / \mu \mathrm{g}$ & Recovery $/ \%$ & $\mathrm{RSD}$ \\
Mushroom & 4.82 & 4.65 & 100.0 & 101.2 & 101.2 & 2.7 \\
Spinach & 6.31 & 6.42 & 100.0 & 98.8 & 98.8 & 0.8 \\
Urine & 2.35 & 2.37 & 100.0 & 97.9 & 97.9 & 3.5 \\
\hline
\end{tabular}

*Average value of five replicate measurements. $\mathrm{RSD}=$ relative standard deviation of 5 individual measurements

Table 2. Comparison of the analytical features of the indicator displacement assay (IDA) chemosensor with the recently reported methods for oxalate determination

\begin{tabular}{|c|c|c|c|c|c|c|c|c|}
\hline No & Probe sensing & $\mathrm{LOD} /(\mu \mathrm{mol} / \mathrm{L})$ & $\begin{array}{c}c(\text { linear range }) / \\
(\mu \mathrm{mol} / \mathrm{L})\end{array}$ & $t($ response)/s & $w($ water $) / \%$ & $\mathrm{pH}$ & $\begin{array}{l}\text { Solid-state deter- } \\
\text { mination limit }\end{array}$ & Reference \\
\hline 1 & $\mathrm{Cu}_{2} \mathrm{PV}$ & n.d. & n.d. & n.d. & HEPES buffer & $5.5-6.5$ & - & (34) \\
\hline 2 & $\mathrm{Cu}_{2} \mathrm{~L}$-eosin & 0.079 & $0.0-5.0$ & n.d. & 100 & 7.0 & - & (35) \\
\hline 3 & $\mathrm{Zn}_{2} \mathrm{~L}_{2}-\mathrm{CAS}$ & 18.7 & n.d. & n.d. & 100 & 7.4 & - & $(2)$ \\
\hline 4 & $\begin{array}{c}\text { GNPs/c-MWCNT/Au } \\
\text { electrode }\end{array}$ & 1.0 & $1.0-800$ & 7 & $\begin{array}{l}\text { sodium succinate } \\
\text { buffer }\end{array}$ & 5.0 & - & (36) \\
\hline 5 & CuRB4 & 0.62 & $1.76-49.4$ & $<60$ & 100 & $5.0-7.0$ & paper test strip & $\begin{array}{c}\text { present } \\
\text { work }\end{array}$ \\
\hline
\end{tabular}

n.d.=not determined

\section{Analytical features of the method}

The analytical features of the colorimetric response of the present chemosensor for determination of oxalate ion were investigated. The calibration curves, attributed to the colorimetric determination of oxalate ion, were constructed using least square regression (Fig. S7 and Fig. S8). According to corresponding calibration curves, limit of detection (LOD) and quantitation (LOQ) were calculated using Eq. 1 and Eq. 2, respectively:

$$
\mathrm{LOD}=\frac{3 \delta}{\mathrm{S}}
$$

and

$$
\mathrm{LOQ}=\frac{10 \delta}{\mathrm{S}}
$$

where $\delta$ is standard deviation, and $S$ is slope.

The absorbance signal of RB4-Cu${ }^{2+}$ increases linearly in the oxalate concentration range of 1.76-49.4 $\mu \mathrm{mol} / \mathrm{L}$ (Fig. S7). The corresponding linear function is:

$$
A_{607 \mathrm{~nm}}=0.2701+874.06 c_{\text {oxalatei }} \mathrm{R}^{2}=0.9983
$$

The limit of detection $(3 \delta / S)$ and the limit of quantification $(10 \delta / S)$ were calculated to be 0.62 and $2.07 \mu \mathrm{mol} / \mathrm{L}$, respectively. These results exhibit excellent sensing performance of the sensor towards oxalate.

Fig. S8 shows the linear relationship of the absorbance signal with $\mathrm{Cu}^{2+}$ concentration coordinated with RB4 for the determination of oxalate in the range of 31 to $100.71 \mu \mathrm{mol} / \mathrm{L}$ with the regression equation:

$$
A_{607 \mathrm{~nm}}=0.31-0.0004 c_{\mathrm{Cu}^{2+}} ; \mathrm{R}^{2}=0.9963
$$

The detection limit $(3 \delta / S)$ of $\mathrm{Cu}^{2+}$ was calculated to be 1.96 $\mu \mathrm{mol} / \mathrm{L}$.

\section{Analytical application}

Since the determination of oxalate ion concentration in food and human body fluids is important, the analytical performance of the proposed chemosensor was examined by analyzing urine, mushroom and spinach samples, which were prepared as described in the materials and methods section. The colorimetric responses of the IDA chemosensor to these samples were evaluated in three replicate measurements. The results are summarized in Table 1.

The analysis of the results of the three samples by the proposed method and the reference method (29) showed good agreement with each other. The RSD values and the range of recoveries (97.9-101.2\%) suggested that the substances in these real samples have no serious interference for the detection of oxalate. Therefore, this chemosensor has potential applications in oxalate detection in real samples.

Table 2 compares the limit of detection, dynamic linear range and analytical parameters of our method with the colorimetric determination of oxalate (2,34-36). Regarding the simplicity of the operation, rapid response and the ability of easy detection, the proposed chemosensor can serve as a probe for the determination of oxalate.

\section{CONCLUSIONS}

In summary, the reaction between $\mathrm{RB} 4$ and $\mathrm{Cu}^{2+}$ to form $\mathrm{RB} 4-\mathrm{Cu}^{2+}$ complex can serve as a simple and inexpensive colorimetric chemosensor for the recognition of oxalate over other available competitive analytes via indicator displacement assay (IDA) in both, the solution (aqueous medium) and solid state (paper-based experiment). There were no significant interferences with other analytes (ascorbic acid and anions) in the determination of oxalate. The absorbance band increase is linear with oxalate concentration from 1.76 to 49.4 $\mu \mathrm{mol} / \mathrm{L}$, with a detection limit of $0.62 \mu \mathrm{mol} / \mathrm{L}$. IMPLICATION logic gate operated using $\mathrm{Cu}^{2+}$ and oxalate as inputs. Determination of oxalate in different real samples such as urine, mushroom and spinach also gave satisfactory results, confirming the applicability of the existing method. 


\section{ACKNOWLEDGEMENT}

The authors are grateful for the support of this work from Payame Noor University Research Council (Shiraz, Iran).

\section{REFERENCES}

1. Singh A, Trivedi DR. Naked-eye detection of biologically important anions in aqueous media by colorimetric receptor and its real life applications. Spectrochim Acta A: Mol Biomol Spectrosc. 2017;179:95-103.

https://doi.org/10.1016/j.saa.2017.02.018

2. Tang L, Wu D, Wen X, Dai X, Zhong K. A novel carbazole-based ratiometric fluorescent sensor for $\mathrm{Zn} 2+$ recognition through excimer formation and application of the resultant complex for colorimetric recognition of oxalate through IDAs. Tetrahedron. 2014;70:9118-24.

https://doi.org/10.1016/j.tet.2014.09.083

3. Nguyen BT, Anslyn EV. Indicator-displacement assays. Coord Chem Rev. 2006;250(23-24):3118-27.

https://doi.org/10.1016/j.ccr.2006.04.009

4. Umali AP, Anslyn EV, Wright AT, Blieden CR, Smith CK, Tian $\mathrm{T}$, et al. Analysis of citric acid in beverages: Use of an indicator displacement assay. J Chem Educ. 2010;87(8):832-5. https://doi.org/10.1021/ed900059n

5. Nguyen BT, Wiskur SL, Anslyn EV. Using indicator-displacement assays in test strips and to follow reaction $\mathrm{ki}$ netics. Org Lett. 2004;6(15):2499-501.

https://doi. org/10.1021/ol0493599

6. Beer PD, Gale PA. Anion recognition and sensing: The state of the art and future perspectives. Angew Chem Int Ed Engl. 2001;40(3):486-516.

https://doi.org/10.1002/1521-3773(20010202)40:3<486: AID-ANIE486>3.0.CO;2-P

7. Zhu Z, Zhou J, Li Z, Yang C. Dinuclear zinc complex for fluorescent indicator-displacement assay of citrate. Sens Actuat B-Chem. 2015;208:151-8. https://doi.org/10.1016/j.snb.2014.11.001

8. Soleymanpour A, Shafaatian B, Mirfakhraei HS, Rezaeifard A. Development of a new chemically modified carbon paste electrode for selective determination of urinary and serum oxalate concentration. Talanta. 2013;116:427-33.

https://doi.org/10.1016/j.talanta.2013.07.002

9. Nizar SA, Mohd Suah FB. Effect of room temperature ionic liquid on the formation of the complex oxalate-sodium morin-5-sulfonate-aluminium(III): Application to the fluorescence determination of oxalate ion. J Fluoresc. 2016;26(4):1167-71.

https://doi.org/10.1007/s10895-016-1845-9

10. Marengo SR, Romani AMP. Oxalate in renal stone disease: The terminal metabolite that just won't go away. Nat Clin Prac Nephrol. 2008; 4(7):368-77.

https://doi.org/10.1038/ncpneph0845
11. Chamjangali MA, Sharif-Razavian L, Yousefi M, Amin AH. Determination of trace amounts of oxalate in vegetable and water samples using a new kinetic-catalytic reaction system. Spectrochim Acta A: Mol Biomol Spectrosc. 2009;73(1):112-6.

https://doi.org/10.1016/j.saa.2009.01.027

12. Borges FT, Michelacci YM, Aguiar JAK, Dalboni MA, Garófalo AS, Schor N. Characterization of glycosaminoglycans in tubular epithelial cells: Calcium oxalate and oxalate ions effects. Kidney Int. 2005;68(4):1630-42. https://doi.org/10.1111/j.1523-1755.2005.00577.x

13. Morakot N, Rakrai W, Keawwangchai S, Kaewtong C, Wanno B. Design and synthesis of thiourea based receptor containing naphthalene as oxalate selective sensor. J Mol Model. 2010;16(1):129-36.

https://doi.org/10.1007/s00894-009-0526-x

14. Li H, Chai XS, DeMartini N, Zhan H, Fu S. Determination of oxalate in black liquor by headspace gas chromatography. J Chromatogr A. 2008;1192(2):208-11. https://doi.org/10.1016/j.chroma.2008.03.066

15. Pérez-Ruiz T, Martínez-Lozano C, Tomás V, Fenoll J. Chemiluminescent determination of oxalate based on its enhancing effect on the oxidation of methyl red by dichromate. Anal Chim Acta. 2005;552(1-2):147-51.

https://doi.org/10.1016/j.aca.2005.07.052

16. Devi R, Relhan S, Pundir CS. Construction of a chitosan/ polyaniline/graphene oxide nanoparticles/polypyrrole/ Au electrode for amperometric determination of urinary/ plasma oxalate. Sens Actuat B-Chem. 2013;186:17-26. https://doi.org/10.1016/j.snb.2013.05.078

17. Chauhan N, Narang J, Shweta, Pundir CS. Immobilization of barley oxalate oxidase onto gold-nanoparticle-porous $\mathrm{CaCO}_{3}$ microsphere hybrid for amperometric determination of oxalate in biological materials. Clin Biochem. 2012; 45(3):253-8.

https://doi.org/10.1016/j.clinbiochem.2011.12.004

18. Milardović S, Kereković I, Nodilo M. A novel biamperometric biosensor for urinary oxalate determination using flow-injection analysis. Talanta. 2008;77(1):222-8.

https://doi.org/10.1016/j.talanta.2008.06.020

19. Chai DF, Wang M, Zhang C, Ning F, Xu W, Pang H, Ma H. A novel 3D POMOF based on dinuclear copper (II)-oxalate complexes and Keggin polyoxoanions with excellent photocatalytic activity. Inorg Chem Commun. 2017;83:16-9. https://doi.org/10.1016/j.inoche.2017.05.028

20. Muñoz JA, López-Mesas M, Valiente M. Development and validation of a simple determination of urine metabolites (oxalate, citrate, uric acid and creatinine) by capillary zone electrophoresis. Talanta. 2010;81(1-2):392-7. https://doi.org/10.1016/j.talanta.2009.12.014

21. Milardović S, Grabarić Z, RumenjakV, Jukić M. Rapid determination of oxalate by an amperometric oxalate oxidase-based 
electrode. Electroanalysis. 2000;12(13):1051-8.

https://doi.org/10.1002/1521-4109(200009)12:

$13<1051:: A I D-E L A N 1051>3.0 . C O ; 2-Z$

22. Zeng JB, Cao YY, Chen JJ, Wang XD, Yu JF, Yu BB, et al. Au@ Ag core/shell nanoparticles as colorimetric probes for cyanide sensing. Nanoscale. 2014;6(17):9939-43.

https://doi.org/10.1039/C4NR02560A

23. Rhaman MM, Fronczek FR, Powell DR, Hossain MA. Colourimetric and fluorescent detection of oxalate in water by a new macrocycle-based dinuclear nickel complex: A remarkable red shift of the fluorescence band. Dalton Trans. 2014;43(12):4618-21. https://doi.org/10.1039/c3dt53467g

24. Mateus $P$, Delgado R, Brandpão $P$, Félix V. Recognition of oxalate by a copper(II) polyaza macrobicyclic complex. Chemistry. 2011;17(25):7020-31. https://doi.org/10.1002/chem.201100428

25. Hu M, Feng G. Highly selective and sensitive fluorescent sensing of oxalate in water. Chem Commun. 2012;48(55): 6951-3. https://doi.org/10.1039/c2cc33191h

26. Tang LJ, Liu MH. A new chemosensing ensemble for colorimetric detection of oxalate in water. Bull Korean Chem Soc. 2010;31(11):3159-62.

https://doi.org/10.5012/bkcs.2010.31.11.3159

27. Yoe JH, Jones AL. Colorimetric determination of iron with disodium-1,2-dihyroxyhexzene-3, 5-disulfonate. Ind Eng Chem Anal Ed. 1944;16(2):111-5. https://doi.org/10.1021/i560126a015

28. Chhakkar AK, Kakkar LR. Extractive spectrophotometric determination of niobium(V) with 3-hydroxy-2-(2-thienyl)-4H-chromen-4-one. Fresenius J Anal Chem. 1995;351 (8):720-3.

https://doi.org/10.1007/BF00323625
29. Khajehsharifi $H$, Sheini A. A selective naked-eye detection and determination of cysteine using an indicator-displacement assay in urine sample. Sens Actuat B-Chem. 2014; 199:457-62.

https://doi.org/10.1016/j.snb.2014.03.055

30. Qian Y, Zhao GJ. The methods of food analysis. Shanghai, PR China: Shanghai Science Popular Publication; 1989; 63:147.

31. Maleki N, Haghighi B, Safavi A. Evaluation of formation constants, molar absorptivities of metal complexes, and protonation constants of acids by nonlinear curve fitting using Microsoft Excel Solver and user-defined function. Microchem J.1999;62(2):229-36.

https://doi.org/10.1006/mchj.1998.1665

32. Yadava PC, Ghose AK, Yadava KL, Dey AK. Stability constants of oxalate complexes of copper (II) and nickel (II) by paper electrophoresis. Chromatographia.1976;9(8):410-2. https://doi.org/10.1007/BF02330393

33. Ou XX, Jin YL, Chen XQ, Gong CB, Ma XB, Wang YS, et al. Colorimetric test paper for cyanide ion determination in real-time. Anal Methods. 2015;7(12):5239-44. https://doi.org/10.1039/C5AY01033K

34. Su J, Sun YQ, Huo FJ, Yang YT, Yin CX. Naked-eye determination of oxalate anion in aqueous solution with copper ion and pyrocatechol violet. Analyst. 2010;135(11):291823.

https://doi.org/10.1039/COAN00620C

35. Hu M, Feng G. Highly selective and sensitive fluorescent sensing of oxalate in water. Chem Commun. 2012;48(55): 6951-3.

https://doi.org/10.1039/C2CC33191H

36. Pundir CS, Chauhan N, Rajneesh, Verma M, Ravi. A novel amperometric biosensor for oxalate determination using multi-walled carbon nanotube-gold nanoparticle composite. Sens Actuat B-Chem. 2011;155(2):796-803. https://doi.org/10.1016/j.snb.2011.01.050 